\title{
Cool-season Turfgrass Color and Growth Habit Response to Elevated Levels of Ultraviolet-B Radiation
}

\author{
Edward J. Nangle ${ }^{1}$, David S. Gardner ${ }^{2}$, James D. Metzger, \\ Dominic P. Petrella, and Tom K. Danneberger \\ Department of Horticulture and Crop Science, 202 Kottman Hall, 2021 \\ Coffey Road, Columbus, OH 43210
}

Luis Rodriguez-Saona

Department of Food Science and Technology, 110 Parker Food Science \& Technology Building, 2015 Fyffe Road, Columbus, OH 43210

John L. Cisar

Department of Environmental Horticulture, 3205 College Avenue, Davie, FL 33314

Additional index words. Schedonorus arundinaceaus, Agrostis stolonifera, Lolium perenne, ultraviolet radiation, turfgrass growth and development, home lawn

\begin{abstract}
Ultraviolet (UV) radiation poses a potential stress for plant growth and development due to its effect on photosynthesis and plant productivity. In the northern hemisphere, peak UV radiation exposure is predicted to occur from 2010 to 2020 , with reduced color from UV-related injury, a possibility for turfgrasses. The objective of this study was to investigate the effects of ultraviolet-B (UV-B) light on turfgrass growth and morphology in three coolseason grasses. Cultivars Barvado tall fescue [Schedonorus arundinaceus (Schreb.) Dumort., nom. cons.], Penncross and L-93 creeping bentgrass (Agrostis stolonifera L.), and Barlenium perennial ryegrass (Lolium perenne $\mathrm{L}$.), were selected because of limited information on their growth and development in elevated UV conditions at heights of cut above $10 \mathrm{~cm}$. The impact of UV-B light treatment on color, relative growth rate, and tillering was measured over a 4-week period in repeated experiments. Ultraviolet-B radiation levels were measured at $16 \mathrm{~kJ} \cdot \mathrm{m}^{-2} \cdot \mathrm{d}^{-1}$ biologically effective UV-B light in growth chambers programmed for a day/night regime of $14 / 10$ hours. Chamber temperatures were maintained at $20^{\circ} \mathrm{C}$ day/ $17{ }^{\circ} \mathrm{C}$ night. Ultraviolet-B light significantly inhibited tiller production in the first experiment in all grasses except $\mathrm{PR}$, whereas no grasses were inhibited in the second experiment. Relative growth rates in all grasses were significantly lower in UV-B conditions 3 weeks after treatment initiation. Turfgrasses exposed to this level of $\mathrm{UV}-\mathrm{B}$ light at typical lawn heights-of-cut had lower color ratings compared with the non-UV-Btreated control at 2 weeks after treatment initiation. The experiments demonstrated that exposure to UV-B resulted in a decline of growth rate and color in cool-season turfgrasses within a timeframe of 2 weeks. Coarse-textured turfgrasses [tall fescue (TF)/perennial ryegrass (PR)] may be more adapted to higher UV-B conditions due to morphological differences compared with the finer textured varieties [creeping bentgrass $(C B)]$.
\end{abstract}

Light plays a crucial role in turfgrass growth and development and is considered most important in wavelengths of $400-700 \mathrm{~nm}$ or photosynthetically active radiation $(P A R)$ (Pons et al., 1993). Light wavelengths and spectral distribution vary with environmental conditions (Bell et al., 2000), and there is interest in how degradation of the ozone layer will influence spectral distribution on the earth's surface (Manney et al., 2011). The decrease in ozone is predicted to significantly increased exposure to

\footnotetext{
Received for publication 17 Apr. 2015. Accepted for publication 26 Jan. 2016.

Salaries and research support provided in part by State and Federal funds appropriated to the Ohio Agricultural Research and Development Center, The Ohio State University. Journal Article HCS-16-12. ${ }^{1}$ Present address: Chicago District Golf Association, 11855 Archer Avenue, Lemont, IL 60439.

${ }^{2}$ Corresponding author. E-mail: Gardner.254@osu.edu.
}

wavelengths in the ultraviolet (UV-A 400-320 $\mathrm{nm} /$ UV-B 320-290 nm/UV-C 290-100 nm) range (Kerr and McElroy, 1993). The UV-B wavelengths that contact the earth's surface are predicted to increase in springtime radiation by $50 \%$ to $60 \%$ from 2010 to 2020 in the northern hemisphere (Taalas et al., 2000). Ultraviolet-B occurs at the range of 290-320 nm (ISO, 2007) and the energy associated with these wavelengths is considered damaging when compared with $P A R$ (Fiscus and Booker, 1995). The reduction in ozone and resulting increase in UV-B has been linked to increased chlorofluorocarbons in the upper atmosphere (Rowland, 1990).

Exposure to UV-B causes several morphological and physiological responses in plants. The leaf area index of some Poaceae can vary in response to different levels of UV-B irradiance with increases from $0 \%$ to $80 \%$ of ambient UV-B resulting in an $88 \%$ decrease in TF leaf area. Increased ambient UV-B from $80 \%$ to $90 \%$, however, resulted in a 20\% increase in specific leaf area (Deckmyn and Impens, 1999). Leaf area increases of $10 \%$ and axillary shoot production of $5 \%$ were noted in response to UV-B exposure in wheat (monocot, Triticum aestivum L.), and a bean (dicot, Phaseolus vulgaris L.) (Barnes et al., 1990). Root length of Arabidopsis was inhibited by almost $80 \%$ after exposure to $2.1 \mu \mathrm{mol} \cdot \mathrm{m}^{-2} \cdot \mathrm{s}^{-1} \mathrm{UV}-\mathrm{B}$ (Kim et al., 2002). Reductions in stem elongation and leaf expansion in young plants of long-spined thorn apple (Datura ferox L.) occur in UV-B light (Ballare et al., 1996). Smaller leaf sizes in white clover (Trifolium repens L.) have been linked to intolerance to UV-B exposure as part of lower constitutive productivity (Hofmann, 2000). In bean plants, low levels of PAR $\left(9.9 \mathrm{~mol} \cdot \mathrm{m}^{-2} \cdot \mathrm{d}^{-1}\right)$ combined with UV-B $\left(0.09 \mathrm{~mol} \cdot \mathrm{m}^{-2} \cdot \mathrm{d}^{-1}\right)$ treatments led to a decrease in leaf area of $47 \%$ and a decrease in leaf dry weight of $\approx 25 \%$ (Cen and Bornman, 1990). Ultraviolet light exposure can reduce photosynthesis by $30 \%$ due to direct damage to photosystem II (Brandle et al., 1977).

Ultraviolet light has varying effects on quality ratings among turfgrasses. Chewings fescue (Festuca rubra L. ssp. commutata Gaud.) is considered the most UV-B-tolerant turfgrass, and kentucky bluegrass Poa pratensis $\mathrm{L}$. is considered the least tolerant (Zhang and Ervin, 2009). Quality ratings were reduced by as much as $74 \%$ for kentucky bluegrass maintained at $5 \mathrm{~cm}$ after $10 \mathrm{~d}$ of exposure to $2.8 \mathrm{~mol} \cdot \mathrm{m}^{-2} \cdot \mathrm{d}^{-1} \mathrm{UV}-\mathrm{B}$. There was cultivar variation in the tolerance of UV-B in the Zhang and Ervin (2009) trial. Darker green kentucky bluegrass cultivars were reported to be more tolerant of UV-B conditions (Ervin et al., 2004). Turfgrass photoinhibition occurs in kentucky bluegrass exposed to $2.8 \mathrm{~mol} \cdot \mathrm{m}^{-2} \cdot \mathrm{d}^{-1} \mathrm{UV}-\mathrm{B}$, maintained at $6.3 \mathrm{~cm}$ through decreasing photochemical efficiency $\left(F_{\mathrm{v}} / F_{\mathrm{m}}\right)$ by $70 \%$ (Zhang et al., 2005). Physiological responses also vary within turfgrass plants with changes in pigmentation not uniform. CB (A. stolonifera) 'L-93' produces more anthocyanins compared with 'Penncross' when exposed to UV-B for $7 \mathrm{~d}$ (Nangle et al., 2015).

Limited research has been conducted to test the effect of UV-B exposure on turfgrasses at higher heights of cut $(10 \mathrm{~cm})$ associated with residential lawns. The estimated area covered by irrigated turfgrass is $163,800 \mathrm{~km}^{2}$ (Milesi et al., 2005), and therefore, a large land area could be affected. The objective of this study was to test three cool-season turfgrasses for their growth rate, tillering, and color responses to elevated UV-B conditions. It was hypothesized that coarser textured species, such as PR and TF (Turgeon, 2008), would have greater tolerance to UV-B than finer textured species such as $\mathrm{CB}$.

\section{Materials and Methods}

Two separate experiments were initiated in Mar. 2011 and May 2011 at The Ohio State University, Columbus, OH. Turfgrasses were 
initially seeded into a mason sand root zone containing $>97 \%$ sand (Hummel \& Co, Trumansburg, NY). Seeding occurred 10 weeks before experimental initiation to allow for establishment into a root zone that met United States Golf Association greens root zone recommendations (USGA, 1993), with a $\mathrm{pH}$ of 7.4 with $2.7 \%$ clay fraction. Single seeds of 'L-93' and 'Penncross' CB, 'Barlenium' $P R$, and 'Barvado' TF were seeded into 3.8-cm-diameter, 21-cm-depth conetainers (Steuwe \& Sons, Tangent, OR). Two cultivars of CB were used due to anecdotal evidence of varying responses to light quantity and source among cultivars. After seeding, conetainers were placed in a mist house under a 10-min irrigation cycle of $15 \mathrm{~s}$ per application to maintain adequate moisture to allow for optimal germination. Turfgrasses were grown under mist for 6 weeks and fertilized with Peters $20 \mathrm{~N} 20 \mathrm{P}_{2} \mathrm{O}_{5} \quad 20 \mathrm{~K}_{2} \mathrm{O}$ (Scotts-Miracle Gro, Marysville, $\mathrm{OH}$ ) at a rate of $11.8 \mathrm{~kg} \mathrm{~N} / \mathrm{ha}$ every 2 weeks. Turfgrass plants were then mowed at a height of $\approx 10 \mathrm{~cm}$ for the rest of the trial and clippings were removed.

Six weeks after seedling emergence, all conetainers were placed in a greenhouse maintained at $\approx 20{ }^{\circ} \mathrm{C}$ for an additional 4 weeks. Imidacloprid (N-\{1-[(6-chloro-3pyridyl)methyl]-4,5-dihydroimidazol-2-yl $\}$ nitramide) (Bayer Environmental Science, Research Triangle Park, NC) was applied at label rates to prevent insect damage. Mefenoxam $\{(R, S)-2-[(2,6$-dimethylphenyl)methoxyacetylamino]-propionic acid methyl ester (Syngenta AG, Greensboro, NC) and thiophanate-methyl [dimethyl 4,4' -ophenylenebis(3-thioallophanate)] (Cleary Chemicals, Dayton, NJ) were applied at label rates for preventative disease control and fertility treatments were maintained at the same rate as previously described. Water was applied for a 5-min period daily to prevent wilt, using an automated ESP modular irrigation system (Rain Bird, Azusa, CA). Following maturation, plants were placed in two Conviron E15 growth chambers (1.4 $\mathrm{m}^{2}$ growth area) and maintained at a height of $116 \mathrm{~cm}$ (Controlled Environment Ltd., Winnipeg, Canada). The chambers were programmed for a day/night length of $14 / 10 \mathrm{~h}$ with a coinciding temperature of $20 / 17^{\circ} \mathrm{C} . P A R$ in the range of 400-700 nm was provided in all chambers using $85 \mathrm{~J} \cdot \mathrm{s}^{-1}$ high-output fluorescent tubes (F12T12-CW.HO; General Electric, Fairfield, CT).

After $24 \mathrm{~h}$ in the growth chambers, UV-B treatment initiation was implemented using UV-B specific lamps having peak wavelength emission at $313 \mathrm{~nm}$, (QUV UV-B 313 nm; Q-Laboratory Corp., Westlake, $\mathrm{OH})$. The control treatment consisted only of PAR. Ultraviolet-B lamps did not produce any extra light in the $P A R$ region and they were burned in for $48 \mathrm{~h}$ to prevent any fluctuation before trial initiation. Radiation from UV sources were measured using both UV-B and UV-A sensors attached to a photometer (IL1350; International Light, Newburyport, MA). All UV radiation is reported as $\mathrm{kJ} \cdot \mathrm{m}^{-2} \cdot \mathrm{d}^{-1}$. The $P A R$ was measured every 15 min during the study using a lightscout quantum cosine corrected light sensor (Spectrum Technologies, Plainfield, IL) connected to a datalogger (Watchdog 300; Spectrum Technologies) and reported as $\mathrm{mol} \cdot \mathrm{m}^{-2} \cdot \mathrm{d}^{-1}$. Water was applied twice daily to prevent wilting. Turfgrass plants were placed $0.8 \mathrm{~m}$ below the lighting in an even spacing of $3.8 \mathrm{~cm}$ and fertilized as previously described.

The growth rate experiment was designed with 1, 2, 3, or 4 weeks of exposure. Under the UV-B and $P A R$ light regimes, there were three blocks with four replications per block in a randomized complete block design (Hammer and Hopper, 1997) for a total of 12 conetainers of each grass per light regime in two repeated experiments. Conetainers were held in three separate trays in three randomized complete blocks and the trays were placed in a row side by side in the chamber. At the end of each week, complete turfgrass plants were destructively harvested and separated into roots and shoots then oven dried at $70{ }^{\circ} \mathrm{C}$ for $2 \mathrm{~d}$. Tissue was dried in an oven (VWR 1350F; Univar USA, Redmond, WA) in $8.9 \times 16.5 \mathrm{~cm}$ coin envelopes (OfficeMax, Naperville, IL). Roots were washed via submergence in a set of four sieves sized $2.00 \mathrm{~mm}, 1.00 \mathrm{~mm}, 850 \mu \mathrm{m}$, and $500 \mu \mathrm{m}$. The shoot:root ratio was then calculated based on dry weight (GwynnJones and Johanson, 1996). Relative growth rate was calculated based on the formula of Gardner et al. (1985):

$$
\mathrm{RGR}=\left(\ln W_{2}-\ln W_{1}\right) /\left(T_{1}-T_{2}\right)
$$

where RGR is the relative growth rate, $W_{2}$ is the total weight at time $T_{2}, W_{1}$ is the total weight at time $T_{1}$.

Table 1. Lighting conditions in control and ultraviolet-treated growth chambers for turfgrasses grown in at The Ohio State University, March-May 2011, for both Expts. 1 and 2.

\begin{tabular}{|c|c|c|c|}
\hline & \multicolumn{3}{|c|}{ Light } \\
\hline & UV-B $(280-320 \mathrm{~nm})$ & UV-A $(320-400 \mathrm{~nm})$ & $P A R(400-700 \mathrm{~nm})$ \\
\hline Chamber & \multicolumn{2}{|c|}{$\mathrm{kJ} \cdot \mathrm{m}^{-2} \cdot \mathrm{d}^{-1}$} & $\mathrm{~mol} \cdot \mathrm{m}^{-2} \cdot \mathrm{d}^{-1}$ \\
\hline Control & 0.0 & 0.1 & 18.6 \\
\hline UV- chamber & $24.0(16.0)^{\mathrm{z}}$ & 0.4 & 18.4 \\
\hline
\end{tabular}

$\mathrm{UV}=$ ultraviolet; $P A R=$ photosynthetically active radiation.

${ }^{\mathrm{z}}$ Actual biologically effective ultraviolet-B radiation (Caldwell, 1971).

Table 2. Relative growth rate for four cool-season grasses grown in control and enhanced ultraviolet-B light conditions. Data combined from two experiments for each grass.

\begin{tabular}{|c|c|c|c|c|}
\hline & \multicolumn{4}{|c|}{ Relative growth rate $\left(\ln \mathrm{g} \cdot \mathrm{m}^{-2} \cdot\right.$ week $\left.^{-1}\right)$} \\
\hline & \multicolumn{4}{|c|}{ Time } \\
\hline & Week 1 & Week 2 & Week 3 & Week 4 \\
\hline & \multicolumn{4}{|c|}{ Tall fescue } \\
\hline$P A R$ & $0.87 \mathrm{a}^{\mathrm{z}}$ & $0.49 \mathrm{a}$ & $1.01 \mathrm{a}$ & $0.15 \mathrm{a}$ \\
\hline$P A R+\mathrm{UV}-\mathrm{B}$ & $0.20 \mathrm{~b}$ & $0.47 \mathrm{a}$ & $1.33 \mathrm{a}$ & $-0.76 \mathrm{~b}$ \\
\hline \multirow[t]{2}{*}{ LSD } & 0.47 & 0.57 & 0.58 & 0.74 \\
\hline & \multicolumn{4}{|c|}{ Perennial ryegrass } \\
\hline$P A R$ & $1.04 \mathrm{a}$ & $0.24 \mathrm{~b}$ & $1.59 \mathrm{a}$ & $0.18 \mathrm{a}$ \\
\hline$P A R+\mathrm{UV}-\mathrm{B}$ & $0.47 \mathrm{~b}$ & $0.82 \mathrm{a}$ & $0.65 \mathrm{~b}$ & $-0.01 \mathrm{a}$ \\
\hline \multirow[t]{2}{*}{ LSD } & 0.44 & 0.52 & 0.48 & 0.22 \\
\hline & \multicolumn{4}{|c|}{ Creeping bentgrass 'Penncross' } \\
\hline$P A R$ & $1.05 \mathrm{a}$ & $1.35 \mathrm{a}$ & $2.43 \mathrm{a}$ & $-0.44 \mathrm{a}$ \\
\hline$P A R+\mathrm{UV}-\mathrm{B}$ & $0.59 \mathrm{a}$ & $0.14 \mathrm{~b}$ & $0.98 \mathrm{~b}$ & $-0.36 \mathrm{a}$ \\
\hline \multirow[t]{2}{*}{ LSD } & 0.54 & 0.61 & 0.65 & 0.97 \\
\hline & \multicolumn{4}{|c|}{ Creeping bentgrass 'L93’ } \\
\hline$P A R$ & $0.88 \mathrm{a}$ & $1.13 \mathrm{a}$ & $2.09 \mathrm{a}$ & $-0.06 \mathrm{a}$ \\
\hline$P A R+$ UV-B & $0.62 \mathrm{a}$ & $0.34 \mathrm{~b}$ & $0.78 \mathrm{~b}$ & $-0.26 \mathrm{a}$ \\
\hline LSD & 0.46 & 0.69 & 0.73 & 0.62 \\
\hline
\end{tabular}

$\mathrm{UV}-\mathrm{B}=$ ultraviolet $\mathrm{B} ; P A R=$ photosynthetically active radiation; $\mathrm{LSD}=$ least significant difference. ${ }^{\mathrm{z}}$ Significant difference between grasses grown in ultraviolet and control conditions on this date $(P=0.05)$. 
After 3-week exposure to light, growth of all grasses except TF in $P A R+\mathrm{UV}-\mathrm{B}$ was significantly inhibited $(P=0.05)$ compared with PAR control chamber grasses (Table 2). There was a decrease in growth rate after grasses were exposed to $P A R$ for 4 weeks; however, the growth rate in $P A R+$ UV-B conditions had become zero as turfgrasses began to decline. There was variability noted within the data, which occurred despite using 12 different samples from each grass at each sampling date.

There was a significant difference $(P=$ $0.05)$ in color ranking for all grasses exposed to $P A R+\mathrm{UV}-\mathrm{B}$ (Fig. 1) at weeks 2-4. PR had a color ranking of 6.4 in $P A R+U V-B$ (Fig. 1A) compared with 7.5 in $P A R$. This was above satisfactory levels, but still significantly lower $(P=0.05)$ than $\mathrm{PR}$ in $P A R$ (Fig. 1A). TF had a rating of 6.1 in $P A R+$ UV-B compared with 7.4 when exposed to $P A R$ (Fig. 1B). This color rating was above satisfactory, but significantly lower than TF plants exposed to $P A R$. CB 'L-93' in $P A R+$ UV-B rated 5.7 for color compared with a PAR color rating of 7.3 (Fig. 1C). CB 'Penncross' color rankings in $P A R+$ UV-B were an unsatisfactory 5.9, whereas in PAR environments, color rankings were 7.1 after 4 weeks of treatment (Fig. 1D). The color rankings for the $\mathrm{CB}$ cultivars in PAR + UV-B were both unsatisfactory and significantly lower $(P=0.05)$ than $\mathrm{CB}$ cultivars exposed to $P A R$ (Fig. $1 \mathrm{C}$ and $\mathrm{D}$ ). Visible damage was clearly seen with browning and yellowing of the leaf tissues. Dark lesions similar to burn spots were noted on the $P A R+\mathrm{UV}$-B-treated $\mathrm{CB}$ plants. The loss of color was not observed until week 2 of the experiments and was consistent in both trials. The color differences were consistent after week 2 and noted at each time period after that. There was some reddening of stems and tissue material, but this was not consistently observed.

Under $P A R+\mathrm{UV}-\mathrm{B}$ conditions in Expt. 1, there was a clear inhibition $(P=0.05)$ of plant tillering in $\mathrm{CB}$ when compared with $P A R$ (Fig. 2). There was a $40 \%$ inhibition of tillering in 'L-93' and 39\% decrease in the 'Penncross'. PR was not inhibited significantly in either experiment. There was a $30 \%$ decrease of TF tillering in Expt. 1, but this did not occur in Expt. 2. No tillering differences among turfgrass species were noted in Expt. 2. The CB exposed to PAR + UV-B had lower tiller numbers in Expt. 1, but they were not significantly different from the PAR treatment in Expt. 2 (data not shown). The root: shoot ratio did not change significantly in response to light regime in either experiment (data not shown).

\section{Discussion}

The decrease in growth rate in $\mathrm{CB}$ after exposure to $P A R+$ UV-B light in this study has previously been reported (Schmidt and Zhang, 2001). Reducing the efficiency of the photosynthetic machinery, because of photolytic damage from UV-B exposure, would effectively reduce plant productivity. This
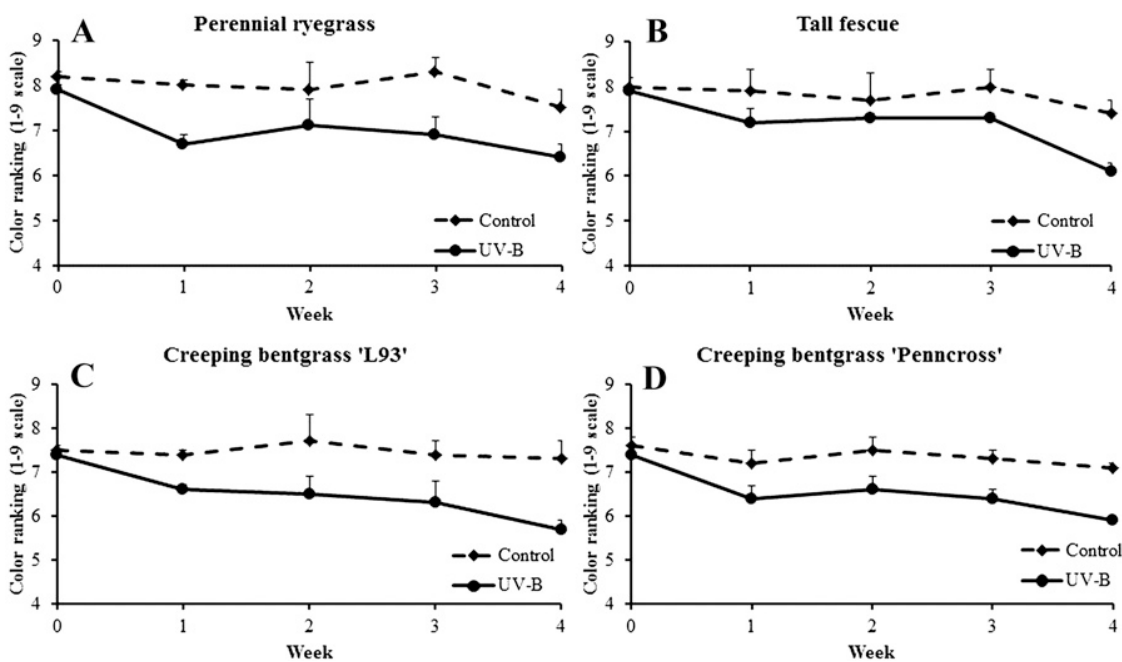

Fig. 1. Color ratings for four cool-season grasses grown in control and enhanced ultraviolet-B light conditions. (A) Perennial ryegrass. (B) Tall fescue. (C) Creeping bentgrass 'L93'. (D) Creeping bentgrass 'Penncross'. Data combined from two experiments for each grass. (1-9 scale, 1 = brown/ dead, $9=$ dark green optimal color, $6=$ acceptable. ${ }^{\text {z }}$ Significant difference between grasses grown in ultraviolet and control conditions on this date $(P=0.05)$.

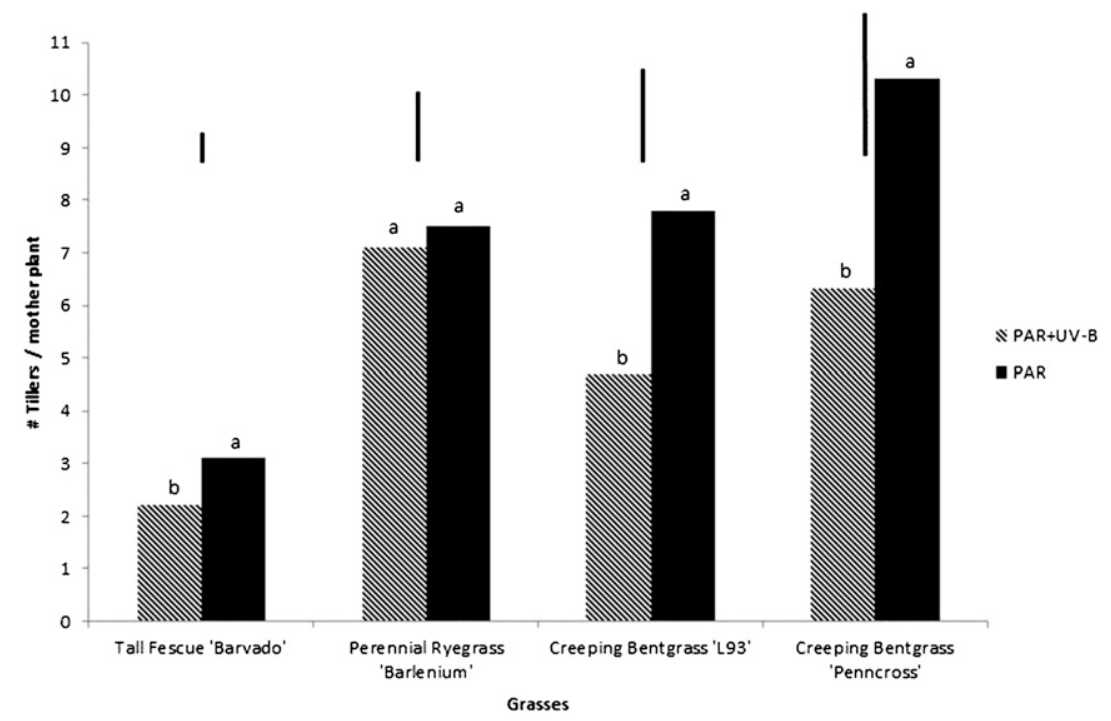

Fig. 2. Number of tillers per mother plant for four cool-season grasses grown in control and enhanced

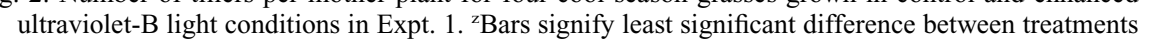
$(P=0.05)$. ${ }^{y}$ Histograms with different letters for each grass signify differences at $P=0.05$.

effect also occurred but to a lesser extent with the TF and PR. The two coarser textured grasses, TF and $\mathrm{PR}$, produced greater growth rates than the finer textured $\mathrm{CB}$ under UV-B stress (Arachevaleta et al., 1989; Pammenter et al., 1986; Sun and Liddle, 1993). Leaf texture may be crucial in maintaining normal growth rates under high $P A R+\mathrm{UV}-\mathrm{B}$ conditions. Epidermal thickness alters leaf absorbance properties and is a predictor of the effectiveness of a plants ability to screen UV-B light (Day, 1993). Breeding of finer textured cultivars the TF and PR in the last decade, however, could influence the response of these turfgrasses to UV-B in the future.

The inhibition of tillering by $P A R+\mathrm{UV}-\mathrm{B}$ in this study could be considered problematic for turfgrass wear recovery, and growth and development. Tillering reduction caused by UV-B has been previously noted in rice (Teramura at al., 1991), but the reduction was not linked to hormonal or carbohydrate changes in plants (Mohammed et al., 2007). In Antarctic hairgrass (Deschampsia antarctica E. Desv.), tillering was increased by UV-B exposure; however, the levels of UV-B in that study measured at $5 \mathrm{~kJ} \cdot \mathrm{m}^{-2} \cdot \mathrm{d}^{-1}$, lower than in our study (Rozema et al., 2001). The variation in tillering from experiment to experiment may have been linked to seasonal variation in light intensity during establishment. The effect of light intensity can lead to changes in both tiller density and also tiller size (Lemaire and Chapman, 1996). The lack of a difference among species in root and shoot growth was somewhat surprising; however, the light levels may have suppressed the 
growth and allocation of carbohydrates equally. This does not agree with previous results (Gwynn-Jones, 2001), but the UV-B levels were higher in our study.

There was some variation in the relative growth rate of the turfgrass varieties, with the CB growth rates reduced by UV-B more than $\mathrm{TF}$ and $\mathrm{PR}$. Varietal growth rate differences in rice (Oryza sativa L.) following exposure to UV have also been observed. Some rice cultivars had a decrease in leaf area by $28 \%$, whereas others only lost $4 \%$ of leaf area. Treatments of UV-B reduced relative growth rate by $7.5 \%$ in one cultivar, whereas others showed little response and these effects were not noted until after 2 weeks of UV-B treatment (Dai et al., 1992). Biomass production of PR and orchardgrass (Dactylis glomerata L.) was reduced in response to comparable spring and summer treatments of elevated UV levels (Deckmyn and Impens, 1999). Variability in response could be related to other factors such as the leaf surface, air temperature, or concentrations of $\mathrm{CO}_{2}$ (Krupa and Kickert, 1989).

In an attempt to gain a consistent turfgrass response, UV-B levels in this study were elevated above current levels to control the turfgrass response. Another goal of this approach was to simulate season-long exposure by supplying extended equivalents of UV-B irradiation. Variation in light intensity plays a key role in responsiveness of plants to both $P A R+\mathrm{UV}-\mathrm{B}$ and $P A R$ irradiance. Its effect varies based on or relative to exposure that is received by plants. In lapland reedgrass (Calamagrostis lapponica) and (Calamgrostis pupurea), levels of UV-B that simulated $15 \%$ loss of ozone resulted in reduced tillering; however, in light levels that simulated $25 \%$ ozone depletion, higher numbers of tillers were produced (GwynnJones and Johanson, 1996). The 25\% ozone depletion equated to a $6.5 \mathrm{~kJ} \cdot \mathrm{m}^{-2} \cdot \mathrm{d}^{-1} \mathrm{UV}-\mathrm{B}$ irradiance, which was lower than that turfgrasses were subjected to in this study. Shortterm exposure to high UB-B $+P A R$ leads to physiological changes in soybean such as increases in pigmentation, but long-term exposure reduces those responses (Grant et al., 2010).

The visual evaluation of color and differences between ratings were similar to previous studies (Millington and King, 2010). The loss of color is one of the principal factors for evaluating turfgrass performance, and while the coarser leaved plants had significant color loss, they still maintained acceptable color levels compared with the two CB cultivars. This may be an important factor to consider regarding tolerance of cool-season grasses to UV light stress.

If the predicted changes in UV light levels occur over time, further research into leaf cuticle thickness and changes in resins and waxes in the cuticular layers will be required. The use of synthetic, reflective type pigments as protective sunscreen type coatings may be an alternative to breeding for increased UV-B tolerance in turfgrasses. Future study of coatings should be conducted to ascertain the effectiveness of such applications.

\section{Literature Cited}

Arachevaleta, M., C.W. Bacon, C.S. Hoveland, and D.E. Radcliffe. 1989. Effect of the tall fescue endophyte on plant response to environmental stress. Agron. J. 81:83-90.

Ballare, C.L., A.L. Scopel, A.E. Stapleton, and M.J. Yanovsky. 1996. Solar ultraviolet-B radiation affects seedling emergence, DNA integrity, plant morphology, growth rate, and attractiveness to herbivore insects in Datura ferox. Plant Physiol. 112:161-170.

Barnes, P.W., S.D. Flint, and M.M. Caldwell. 1990. Morphological responses of crop and weed species of different growth forms to ultraviolet-B radiation. Amer. J. Bot. 77:1354-1360.

Bell, G.E., T.K. Danneberger, and M.J. McMahon. 2000. Spectral irradiance available for turfgrass growth in sun and shade. Crop Sci. 40:189195.

Brandle, J.R., W.F. Campbell, W.B. Sisson, and M.M. Caldwell. 1977. Net photosynthesis, electron transport capacity, and ultrastructure of Pisum sativum L. exposed to ultraviolet-B radiation. Plant Physiol. 60:165-169.

Caldwell, M.M. 1971. Solar ultraviolet radiation and the growth and development of higher plants, p. 131-177. In: A.C. Giese (ed.). Photophysiology Academic Press, New York, NY.

Cen, Y.-P. and J.F. Bornman. 1990. The response of bean plants to UV-B radiation under different irradiances of background visible light. J. Expt. Bot. 41:1489-1495.

Dai, Q., V.P. Coronel, B.S. Vergara, P.W. Barnes, and A.T. Quintos. 1992. Ultraviolet-B radiation effects on growth and physiology of four rice cultivars. Crop Sci. 32:1269-1274.

Day, T.A. 1993. Relating UV-B radiation screening effectiveness of foliage to absorbingcompound concentration and anatomical characteristics in a diverse group of plants. Oecologia 95:542-550.

Deckmyn, G. and I. Impens. 1999. Seasonal responses of six Poaceae to differential levels of solar UV-B radiation. Environ. Expt. Bot. 41:177-184

Ervin, E.H., X. Zhang, and J.H. Fike. 2004 Ultraviolet-B radiation damage on Kentucky bluegrass. III. cultivar effects. HortScience 39:1475-1477.

Fiscus, E.L. and F.L. Booker. 1995. Is increased UV-B a threat to crop photosynthesis and productivity? Photosynth. Res. 43:81-92.

Gardner, F.P., R.B. Pearce, and R.L. Mitchell. 1985. Physiology of crop plants. Iowa State Univ. Press, Ames, IA.

Grant, R.H., K.G. Apostol, and H. F. Schmitz. 2010. Physiological impacts of short-term UV irradiance exposures on cultivars of Glycine Max. UV Radiation in Global Climate Change. 458-487.

Gwynn-Jones, D. 2001. Short-term impacts of enhanced UV-B radiation on photo-assimilate allocation and metabolism: A possible interpretation for time-dependent inhibition of growth. Plant Ecol. 154:67-73.

Gwynn-Jones, D. and U. Johanson. 1996. Growth and pigment production in two subarctic grass species under four different UV-B irradiation levels. Physiol. Plant. 97:701-707.

Hammer, P.A. and D.A. Hopper. 1997. Experimental design, p. 177-188. In: R.W. Langhans and T.W. Tibbitts (eds.). Plant growth chamber handbook. North Central Regional Research publication 340 .

Hofmann, R.W. 2000. Population studies of ultraviolet-B radiation responses in white clover (Trifolium repens L.). Massey University,
Palmerston North, New Zealand PhD Thesis. 13 Mar. 2016. <http://mro.massey.ac.nz/xmlui/ bitstream/handle/10179/2248/02_whole.pdf? sequence $=1 \&$ is Allowed $=\mathrm{y}>$.

ISO. 2007. International standard ISO 21348 , Space environment (natural and artificial)Process for determining solar irradiances. 1st ed. 13 Mar. 2016. <www.iso.org>.

Kerr, J.B. and C.T. McElroy. 1993. Evidence for large upward trends of ultraviolet-B radiation linked to ozone depletion. Sci. 262:1032-1034.

Kim, B.C., D.J. Tennessen, and R.L. Last. 2002. UV-B-induced photomorphogenesis in Arabidopsis thaliana. Plant J. 15:667-674.

Krupa, S.V. and R.N. Kickert. 1989. The greenhouse effect: Impacts of ultraviolet-B (UV-B) radiation, carbon dioxide $\left(\mathrm{CO}_{2}\right)$, and ozone $\left(\mathrm{O}_{3}\right)$ on vegetation. Environ. Pollut. 61:263-393.

Lemaire, G. and D. Chapman. 1996. Tissue flows in grazed plant communities, p. 3-36. In: J. Hodgson and A.W. Illius, (eds.). The ecology and management of grazing systems, CAB International, London.

Manney, G.L., M.L. Santee, M. Rex, N.J. Livesey, M.C. Pitts, P. Veefkind, E.R. Nash, I. Wohltmann, R. Lehmann, L. Froidevaux, L.R. Poole, M.R. Schoeberl, D.P. Haffner, J. Davies, V. Dorokhov, H. Gernandt, B. Johnson, R. Kivi, E. Kyrö, N. Larsen, P.F. Levelt, A. Makshtas, C.T. McElroy, H. Nakajima, M.C. Parrondo, D.W. Tarasick, P. von der Gathen, K.A. Walker, and N.S. Zinoviev. 2011. Unprecedented Arctic ozone loss in 2011. Nature 478:469-475.

Milesi, C., S.W. Running, C.D. Elvidge, J.B. Dietz, and B.T. Tuttle. 2005. Mapping and modeling the biogeochemical cycling of turf grasses in the United States. Environ. Mgt. 36:426-438.

Millington, K.R. and A.L. King. 2010. Measuring colour and photostability of small fleece wool samples. Anim. Prod. Sci. 50:589-592.

Mohammed, A.R., E.W. Rounds, and L. Tarpley. 2007. Response of rice (Oryza sativa L.) tillering to sub-ambient levels of ultraviolet-B radiation. J. Agron. Crop Sci. 193:324-335.

Nangle, E.J., D.S. Gardner, J.D. Metzger, L.E Rodriguez-Saona, M.M. Guisti, T.K. Danneberger, and D.P. Petrella. 2015. Pigment changes in cool-season turfgrasses in response to ultraviolet-B light irradiance. Agron. J. 107:41-50.

Pammenter, N.W., P.M. Drennan, and V.R. Smiths. 1986. Physiological and anatomical aspects of photosynthesis of two Agrostis species at a sub-Antarctic island. New Phytol. 102:143-160.

Pons, T.L., H. van Rijnberk, I. Scheurwater, and A. van der Werf. 1993. Importance of the gradient in photosynthetically active radiation in a vegetation stand for leaf nitrogen allocation in two monocotyledons. Oecologia 95:416-424.

Rozema, J., R. Broekman, D. Lud, Ad H. J. Huiskes, T. Moerdijk, N. de Bakker, B. Meijkamp, and A. van Beem. 2001. Consequences of depletion of stratospheric ozone for terrestrial Antarctic ecosystems: The response of Deschampsia antarctica to enhanced UV-B radiation in a controlled environment. Plant Ecol. 154:101-115.

Rowland, F.S. 1990. Stratospheric ozone depletion by chlorofluorocarbons. Ambio 19:281-292.

SAS Version 9.2. SAS Copyright, 2002-2008 by SAS Institute Inc., Cary, NC.

Schmidt, R.E. and X. Zhang. 2001. Alleviation of photochemical activity decline of turfgrasses exposed to soil moisture stress or UV radiation. Intl. Turfgrass Res. J. 9:340-346.

Sun, D. and M.J. Liddle. 1993. Plant morphological characteristics and resistance to simulated trampling. Environ. Mgt. 17:511-521. 
Taalas, P., J. Kaurola, A. Kylling, D. Shindell, R. Sausen, M. Dameris, V. Grewe, J. Herman, J. Damski, and B. Steil. 2000. The impact of greenhouse gases and halogenated species on future solar UV radiation doses. Geophys. Res. Lett. 27:1127-1130.

Teramura, A.H., L.H. Ziska, and A.E. Sztein. 1991. Changes in growth and photosynthetic capacity of rice with increased UV-B radiation. Physiol. Plant. 83:373-380.

Turgeon, A.J. 2008. Turfgrass management 8 th ed. 7-8. Pearson Education Inc., Upper Saddle River, NJ.

USGA. 1993. USGA recommendations for putting green construction. USGA Green Section Record. 31:1-3.
Zhang, X., E.H. Ervin, and R.E. Schmidt. 2005. The role of leaf pigment and antioxidant levels in UV-B resistance of dark- and light-green Kentucky bluegrass cultivars. J. Amer. Soc. Hort. Sci. 130:836-841.

Zhang, X. and E.H. Ervin. 2009. Physiological assessment of cool-season turfgrasses under ultraviolet-B stress. HortScience 44:1785-1789. 